\title{
The role of 25-hydroxyvitamin-D3 and vitamin $D$ receptor gene in human periodontal ligament fibroblasts as response to orthodontic compressive strain: an in vitro study
}

Erika Calvano Küchler ${ }^{1}$, Agnes Schröder ${ }^{1}$, Vinicius Broska Teodoro ${ }^{2}$, Ute Nazet ${ }^{1}$, Rafaela Scariot ${ }^{3}$, Gerrit Spanier ${ }^{4}$, Peter Proff' and Christian Kirschneck ${ }^{1 *}$

\begin{abstract}
Background: This study aimed to investigate, if different physiological concentrations of vitamin $\mathrm{D}\left(25(\mathrm{OH}) \mathrm{D}_{3}\right)$ and single nucleotide polymorphisms in vitamin $D$ receptor (VDR) gene have an impact on gene expression in human periodontal ligament (hPDL) fibroblasts induced by simulated orthodontic compressive strain.

Methods: A pool of hPDL fibroblasts was treated in absence or presence of $25(\mathrm{OH}) \mathrm{D}_{3}$ in 3 different concentrations (10, 40 and $60 \mathrm{ng} / \mathrm{ml})$. In order to evaluate the role of single nucleotide polymorphisms in the VDR gene, hPDL fibroblasts from 9 patients were used and treated in absence or presence of $40 \mathrm{ng} / \mathrm{ml} 25(\mathrm{OH}) \mathrm{D}_{3}$. Each experiment was performed with and without simulated orthodontic compressive strain. Real-time PCR was used for gene expression and allelic discrimination analysis. Relative expression of dehydrocholesterol reductase (DHCR7), Sec23 homolog A, amidohydrolase domain containing 1 (AMDHD1), vitamin D 25-hydroxylase (CYP2R1), Hydroxyvitamin D-1-a hydroxylase, receptor activator of nuclear factor-KB ligand (RANKL), osteoprotegerin (OPG), cyclooxygenase-2 (COX-2) and interleukin-6 (IL6) was assessed. Three single nucleotide polymorphisms in VDR were genotyped. Parametric or nonparametric tests were used with an alpha of $5 \%$.
\end{abstract}

Results: RANKL, RANKL:OPG ratio, COX-2, IL-6, DHCR7, CYP2R1 and AMDHD1 were differentially expressed during simulated orthodontic compressive strain $(p<0.05)$. The RANKL:OPG ratio was downregulated by all concentrations $(10 \mathrm{ng} / \mathrm{ml}, 40 \mathrm{ng} / \mathrm{ml}$ and $60 \mathrm{ng} / \mathrm{ml})$ of $25(\mathrm{OH}) \mathrm{D}_{3}$ (mean $=0.96 \pm 0.68$, mean $=1.61 \pm 0.66$ and mean $=1.86 \pm 0.78$, respectively) in comparison to the control (mean $2.58 \pm 1.16)(p<0.05)$. CYP2R1 gene expression was statistically modulated by the different $25(\mathrm{OH}) \mathrm{D}_{3}$ concentrations applied $(p=0.008)$. Samples from individuals carrying the $\mathrm{GG}$ genotype in rs 739837 presented lower VDR mRNA expression and samples from individuals carrying the CC genotype in rs7975232 presented higher VDR mRNA expression $(p<0.05)$.

Conclusions: Simulated orthodontic compressive strain and physiological concentrations of $25(\mathrm{OH}) \mathrm{D}_{3}$ seem to regulate the expression of orthodontic tooth movement and vitamin-D-related genes in periodontal ligament fibroblasts

*Correspondence: christian.kirschneck@klinik.uni-regensburg.de

1 Department of Orthodontics, University of Regensburg,

Franz-Josef-Strauss-Allee 11, 93053 Regensburg, Germany

Full list of author information is available at the end of the article

(c) The Author(s) 2021. Open Access This article is licensed under a Creative Commons Attribution 4.0 International License, which permits use, sharing, adaptation, distribution and reproduction in any medium or format, as long as you give appropriate credit to the original author(s) and the source, provide a link to the Creative Commons licence, and indicate if changes were made. The images or other third party material in this article are included in the article's Creative Commons licence, unless indicated otherwise in a credit line to the material. If material is not included in the article's Creative Commons licence and your intended use is not permitted by statutory regulation or exceeds the permitted use, you will need to obtain permission directly from the copyright holder. To view a copy of this licence, visit http:/creativecommons.org/licenses/by/4.0/ The Creative Commons Public Domain Dedication waiver (http//creativeco mmons.org/publicdomain/zero/1.0/) applies to the data made available in this article, unless otherwise stated in a credit line to the data. 
in the context of orthodontic compressive strain. Our study also suggests that single nucleotide polymorphisms in the VDR gene regulate VDR expression in periodontal ligament fibroblasts in the context of orthodontic compressive strain.

Keywords: Vitamin D, Tooth movement, Polymorphism, Gene

\section{Introduction}

The periodontal ligament (PDL) is a connective tissue located between the cementum of teeth and the alveolar bone and mainly composed of fibroblast-like cells, characterized by collagen production, but also possessing some osteoblastic features [1]. The PDL actively participates in alveolar bone remodeling, which is the key component of orthodontic tooth movement (OTM) to therapeutically correct the position of misaligned teeth within the alveolar bone of the upper and lower jaws [2]. OTM is induced by the application of a mechanical force to a tooth by orthodontic appliances leading to the formation of tensile and pressure zones within the PDL [3]. As a reaction, PDL fibroblasts produce several proinflammatory mediators, when stimulated mechanically [4-8], leading to a sterile inflammatory reaction within the PDL, which ultimately induces osteoclast differentiation and activity [3]. PDL fibroblasts thus play a major role in mediating the molecular processes required for OTM [9].

Previous studies in orthodontics evaluated many factors that could be accountable for individual variations in the tissue response to OTM therapy [10-12]. Among these, vitamin $\mathrm{D}$ is known to regulate osteogenic differentiation in the PDL [13], affecting the adjacent alveolar bone [14], and previous studies reported a vitamin-D-associated enhancement of OTM [10-12, 15] as well as a reduced tendency for relapse after OTM [15]. Vitamin D is a liposoluble secosteroid essential for the body's bone balance [16]. To become metabolically active, vitamin $\mathrm{D}$ is first converted to $25(\mathrm{OH}) \mathrm{D}_{3}$, also known as calcifediol, which is then converted into the active form of vitamin $\mathrm{D}$ calcitriol $\left(1,25(\mathrm{OH}) 2 \mathrm{D}_{3}\right)$ [17]. The biological effects of vitamin D are mediated by binding to its intracellular receptor, the vitamin $\mathrm{D}$ receptor (VDR), a member of the nuclear receptor superfamily [18]. Additionally to the $V D R$, some other vitamin D-related genes are also closely related to the synthesis, activation and degradation of vitamin $\mathrm{D}$ such as 7-dehydrocholesterol reductase (DHCR7), Sec23 homolog A (SEC23A), amidohydrolase domain containing 1 (AMDHD1), vitamin D 25-hydroxylase (CYP2R1) and Hydroxyvitamin D-1- $\alpha$ hydroxylase (CYP27B1) $[17,19]$. VDR mediates the activities of vitamin $D$ binding sites in the DNA stimulating the physiological regulation of several genes $[17,18]$, including receptor activator of nuclear factor- $\kappa B$ ligand (RANKL), osteoprotegerin (OPG), cyclooxygenase-2 (COX-2) and interleukin-6 (IL6), which are involved in OTM [8, 20, 21].

The gene encoding the VDR in humans is located on chromosome 12q13.11, which spans $\sim 100 \mathrm{~kb}$ and has five promotors, eight coding exons and six untranslated exons [22]. The $V D R$ gene is known to exhibit many polymorphic regions [23, 24], including single nucleotide polymorphisms (SNPs), which influence the expression/functions of $V D R$ and have been associated with complex traits, including oral phenotypes, such as periodontal disease $[25,26]$ and external apical root resorption as a sequela of orthodontic treatment [27].

Vitamin D presence $[28,29]$ and VDR expression [13, 14, 30-32] were observed in human periodontal soft tissues and cells. Furthermore, animal model studies indicate that vitamin D deficiency as well as its therapeutic supplementation or local administration can impact on the rate of OTM and the stability of tooth position after orthodontic treatment [33]. As of now, however, it is not clear, how vitamin $\mathrm{D}$ impacts gene expression pattern of PDL fibroblasts in the context of simulated orthodontic compressive strain and whether SNPs in the $V D R$ genes can account for individual expression differences. Our hypothesis is that vitamin D levels and SNPs in the $V D R$ gene influence gene expression during OTM. Therefore, the purpose of the present study was to investigate, if different physiological concentrations of $25(\mathrm{OH}) \mathrm{D}_{3}$ influence the expression of OTM-related genes and vitamin-D-related genes in human PDL (hPDL) fibroblasts as response to simulated orthodontic compressive strain and whether common SNPs in VDR are involved in individual variations of gene expression pattern.

\section{Methods}

This in vitro study aimed to investigate the influence of physiological concentrations of $25(\mathrm{OH}) \mathrm{D}_{3}$ and SNPs in $V D R$ in simulated orthodontic compressive strain. The ethics committee of the University of Regensburg, Germany, approved the collection of the samples and the subsequent experiments (Approval No. 12-170-0150). Informed written consent was obtained with an assent document from all subjects. 


\section{In vitro setup for cell culture experiments}

For this experiment, hPDL fibroblasts from periodontal connective tissue were used. hPDL from permanent caries-free teeth, extracted in a routine dental treatment at the maxillofacial surgery clinic at the University of Regensburg, were collected, isolated, cultivated and characterised according to an established method and protocol previously published $[5,6]$. Briefly, hPDL fibroblasts from the third to fifth passages were seeded at a density of 70.000 cells per well into standard six-well cell culture plates. To simulate orthodontic compressive strain in hPDL pressure areas, a physiological compressive force of $2 \mathrm{~g} / \mathrm{cm}^{2}$ was applied to the hPDL fibroblasts under cell culture conditions at 70\% confluency for $48 \mathrm{~h}$, using a glass disc [5,6]. Figure 1 shows the setup of the in vitro experiment. Two experimental designs were carried out:

1. Evaluation of the effects of different concentrations of $25(\mathrm{OH}) \mathrm{D}_{3}$ during orthodontic compressive strain-stimulation of hPDL fibroblasts pooled from six patients, as previously established and described $[6,8]$, was performed either in absence or presence of $25(\mathrm{OH}) \mathrm{D}_{3}(1 \mathrm{mg}$, Tocris/Bio-Techne, Wiesbaden, Germany) in 3 different concentrations established according to The Endocrine Society's Clinical Guide- lines [34]: $10 \mathrm{ng} / \mathrm{ml}$ (vitamin-D-deficient), $40 \mathrm{ng} / \mathrm{ml}$ (vitamin-D-sufficient) and $60 \mathrm{ng} / \mathrm{ml}$ (vitamin-D-sufficient simulating supplementation) (Fig. 1). Each of the experimental groups included three samples and three wells, with and without simulated orthodontic compressive strain. After $48 \mathrm{~h}$ mRNA expression levels of OTM-related genes and vitamin-D-related genes were evaluated.

2. Influence of SNPs in $V D R$ gene on the cellular response to orthodontic compressive strain-stimulation was performed in individual samples from nine patients/teeth in triplicates (three wells) either in absence or presence of $40 \mathrm{ng} / \mathrm{ml}$ of $25(\mathrm{OH}) \mathrm{D}_{3}(1 \mathrm{mg}$, Tocris/Bio-Techne, Wiesbaden, Germany). Each experimental group included three wells, with and without simulated orthodontic compressive strain. After $48 \mathrm{~h}$ mRNA expression levels of $V D R$ and the SNPs FokI, BglI and Apal in VDR were evaluated.

\section{Total RNA isolation and quantification of relative gene expression (RT-qPCR)}

Total RNA from hPDL fibroblasts was extracted using $1 \mathrm{ml}$ peqGOLD TriFast ${ }^{\mathrm{TM}}$ (PEQLAB Biotechnology $\mathrm{GmbH}$, Erlangen, Germany) according to the

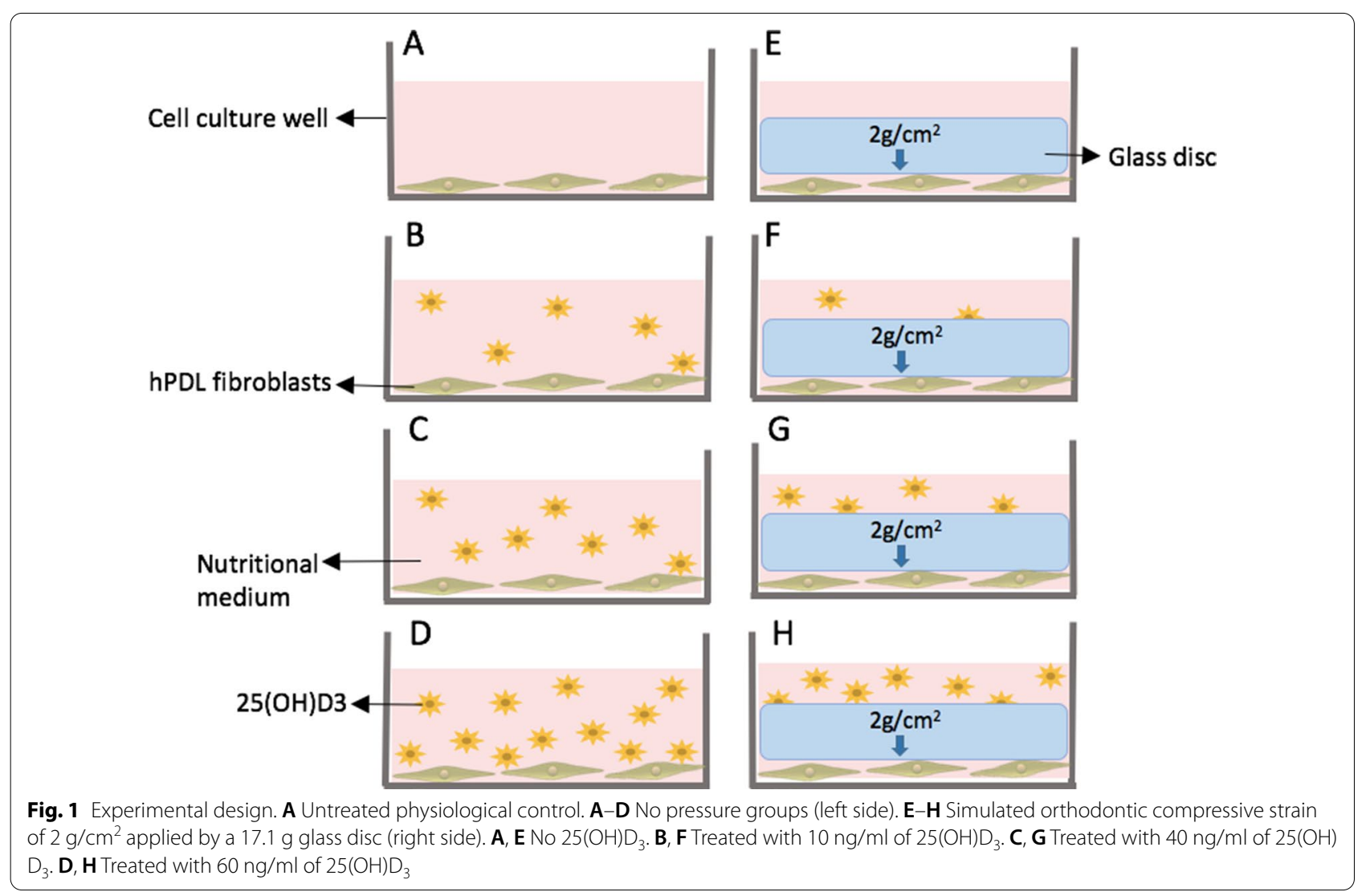


manufacturer's instructions. The RNA was instantaneously cooled on ice. For quantification and purity evaluation of the total RNA, optical density was photometrically measured at $280 \mathrm{~nm}, 260 \mathrm{~nm}$ and $230 \mathrm{~nm}$ (NanoPhotometer N60, Implen, Munich, Germany), as previously described $[5,6]$.

For complementary DNA (cDNA) synthesis, a standardized amount of 500 ng RNA per sample was transcribed and RT-qPCR amplification was performed with a Mastercycler ${ }^{\circledR}$ ep realplex-S thermocycler (Eppendorf AG, Hamburg, Germany) [5, 6]. Quantification cycle $(\mathrm{Cq})$ values were determined as second derivative maximum of the fluorescence signal curve as previously described [35] using the software Realplex (version 2.2, Eppendorf AG, CalqPlex algorithm, Automatic Baseline, Drift Correction On) and the arithmetic mean of each duplicate Cq per gene and sample was used. For normalization of target genes, PPL22 and PPIB previously established reference genes stable in hPDL fibroblasts were used [5]. The studied target genes and reference genes are described in the Additional file 1: Table S1.

Relative gene expression was calculated as $2^{-\Delta \mathrm{Cq}}$ with $\Delta \mathrm{Cq}=\mathrm{Cq}$ (target gene) $-\mathrm{Cq}$ (mean RPL22/PPIB), divided by the respective arithmetic $2^{-\Delta \mathrm{Cq}}$ mean of the untreated controls (for each experimental group) to established the relative gene expression. The gene-specific primers were designed according to MIQE quality guidelines using NCBI Primer-BLAST and additional software. The primers were synthesized and purified by Eurofins MWG Operon LLC (Huntsville, AL, USA; High Purity Salt Free Purification $\mathrm{HPSF}^{\circledR}$ ). For each primer pair and qPCR run a no template control without cDNA was tested to assess a possible bias in results by primer dimers or contaminating DNA.

\section{Genomic DNA isolation and allelic discrimination analysis} Genomic DNA (gDNA) of hPDL cells of 9 patients was extracted using the GenElute Mammalian Genomic DNA Miniprep kit (Sigma Aldrich, Munich, Germany) according to the manufacturer's instructions. For purity evaluation and DNA quantification optical density was photometrically measured at $260 \mathrm{~nm}$ and $230 \mathrm{~nm}$ (NanoPhotometer N60, Implen, Munich, Germany). The $\mathrm{OD}_{260 \mathrm{~nm} / 280 \mathrm{~nm}}$ ratio $>1.8$ indicated protein-free DNA.

The SNPs rs2228570 (FokI, A > G/Met > Thr), rs739837 (BglI, G>T/intronic) and rs7975232 (ApaI, A $>\mathrm{C}$ / intronic) in $V D R$ were selected based on their minor allele frequency and their previously reported association. Genotyping was performed by allelic discrimination real-time PCR using the TaqMan assay in the Mastercy$\mathrm{cler}^{\circledR}$ ep realplex-S thermocycler (Eppendorf AG, Hamburg, Germany) as described before [8].

\section{Statistical analysis}

The software GraphPad Prism 8.0.1 (GraphPad Software Inc., San Diego, USA) was used for statistical analyses. Prior to the statistical analysis, all absolute data values were divided by the respective arithmetic mean of the respective untreated control group to obtain normalised data values relative to the values of the controls, which were set to 1 . The Shapiro-Wilk test was used to assess the normality of the gene expression data and Levene's test to determine homogeneity of variance across groups. Parametric tests (ANOVA and $t$ tests) were used to compare relative gene expression between groups. Non-parametric tests (Kruskal-Wallis in the co-dominant model and Mann-Whitney in the recessive model) were used to compare relative gene expression between individual sample genotypes. Posthoc tests were performed using Tukey's (ANOVA) or Dunn's (Kruskal-Wallis) tests. Statistical significance was established at $p<0.05$.

\section{Results}

Effects of simulated orthodontic compressive strain and $25(\mathrm{OH}) \mathrm{D}_{3}$ on the expression of OTM-related genes and vitamin-D-related genes

Simulated orthodontic compressive strain impacted on gene expression. A statistically significant overexpression during simulated orthodontic compressive was observed for RANKL $(p=0.002$ at $0 \mathrm{ng} / \mathrm{ml}$ and $p=0.001$ at $60 \mathrm{ng} / \mathrm{ml})$; the RANKL:OPG ratio $(p=0.01$ at $0 \mathrm{ng} / \mathrm{ml}, p=0.042$ at $40 \mathrm{ng} / \mathrm{ml}$ and $p=0.033$ at $60 \mathrm{ng} /$ $\mathrm{ml})$; COX-2 $(p=0.002$ at $0 \mathrm{ng} / \mathrm{ml}, p=0.001$ at $10 \mathrm{ng} / \mathrm{ml}$, $p=0.002$ at $40 \mathrm{ng} / \mathrm{ml}$ and $p=0.019$ at $60 \mathrm{ng} / \mathrm{ml}) ; \mathrm{IL}-6$ $(p=0.002$ at $0 \mathrm{ng} / \mathrm{ml}, p=0.002$ at $10 \mathrm{ng} / \mathrm{ml}, p=0.028$ at $40 \mathrm{ng} / \mathrm{ml}$ and $p=0.038$ at $60 \mathrm{ng} / \mathrm{ml})$; DHCR7 $(p=0.013$ at $0 \mathrm{ng} / \mathrm{ml}, p=0.006$ at $10 \mathrm{ng} / \mathrm{ml}$ and $p=0.004$ at $40 \mathrm{ng} /$ $\mathrm{ml})$; and CYP2R1 ( $p=0.02$ at $0 \mathrm{ng} / \mathrm{ml})$. AMDHD1 was downregulated during simulated orthodontic compressive strain $(p=0.006$ at $40 \mathrm{ng} / \mathrm{ml}$ and $p=0.048$ at $60 \mathrm{ng} / \mathrm{ml}$ ). The gene expression data are presented in the Additional file 1: Table S2.

The Fig. 2 shows the effects of different concentrations of $25(\mathrm{OH}) \mathrm{D}_{3}$ during simulated orthodontic compressive strain on the relative expression of RANKL, OPG, the RANKL:OPG ratio, COX-2, IL-6, VDR, DHCR7, SEC23A, AMDHD1, CYP2R1 and CYP27B1. Treatment with $25(\mathrm{OH}) \mathrm{D}_{3}$ impacted on the RANKL:OPG ratio levels during simulated orthodontic compressive strain in all evaluated concentrations $(10 \mathrm{ng} / \mathrm{ml}, 40 \mathrm{ng} / \mathrm{ml}$ and $60 \mathrm{ng} / \mathrm{ml})(p<0.05) .25(\mathrm{OH}) \mathrm{D}_{3}$ at a concentration of $40 \mathrm{ng} / \mathrm{ml}$ was also associated with CYP2R1 expression $(p<0.05)$. 


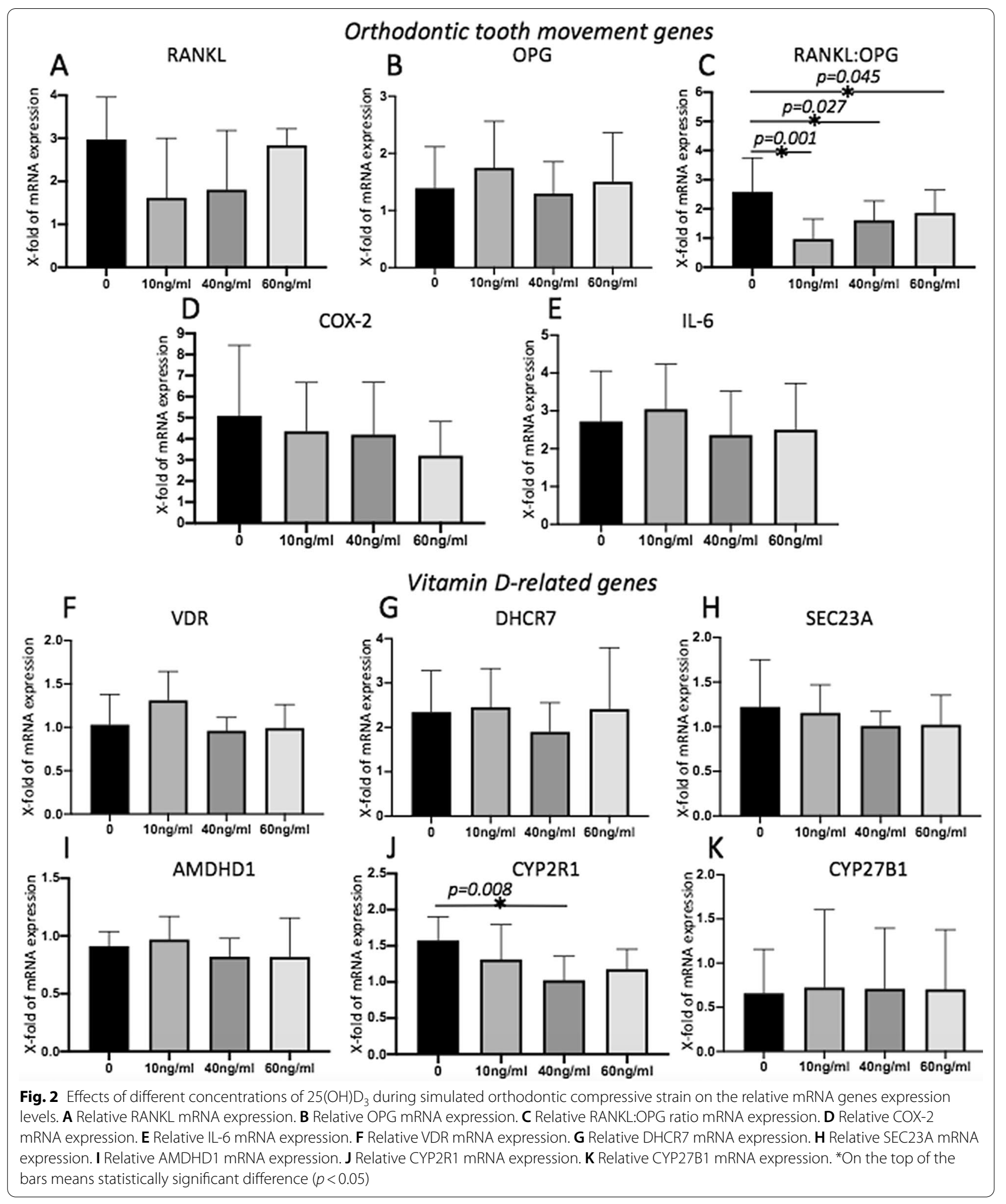


The role of different SNPs within the VDR gene for gene expression response (mRNA) to vitamin D

The relative mRNA $V D R$ expression according to the genotypes of FokI (rs2228570), BglI (rs739837) and ApaI (rs7975232) in the VDR gene and the genotype distribution for each SNP are presented in Table 1. A statistically significant difference was observed in a codominant model in the SNP rs7975232. Samples from individuals carrying the $\mathrm{CC}$ genotype presented higher relative $V D R$ mRNA expression than the samples from individuals carrying the AC genotype under simulated orthodontic compressive strain (pressure).

Statistical significance was also observed in a recessive model. With simulated orthodontic compressive strain (pressure) samples from individuals carrying the CC genotype presented higher relative $V D R$ mRNA expression than samples from individuals carrying at least one A allele (AC + AA genotypes) in SNP rs7975232. Without simulated orthodontic compressive strain (no pressure), samples from individuals carrying the GG genotype presented lower $V D R$ mRNA expression than samples from individuals carrying at least one T allele $(\mathrm{GT}+\mathrm{TT}$ genotypes) in rs739837 during treatment with $40 \mathrm{ng} /$ $\mathrm{ml}$ of $25(\mathrm{OH}) \mathrm{D}_{3}$. With simulated orthodontic compressive strain (pressure) samples from individuals carrying the CC genotype presented higher relative $V D R$ mRNA expression than samples from individuals carrying at least one A allele (AC+AA genotypes) in rs7975232.

\section{Discussion}

Although the connection between vitamin $\mathrm{D}$, vitamin $\mathrm{D}$ receptor (VDR) and orthodontic phenotypes is not a new subject in the literature and has been investigated by some dental researchers in the past three decades [33], the role of vitamin $\mathrm{D}$ as a therapeutical adjunct during OTM is still controversial and the molecular processes occurring during OTM under the influence of vitamin D are largely unknown. Therefore, this in vitro study aimed to investigate, if $25(\mathrm{OH}) \mathrm{D}_{3}$ impacts on the expression of some genes involved in the response of hPDL fibroblasts to simulated orthodontic compressive strain. To answer this question, we investigated the effect of different concentrations of $25(\mathrm{OH}) \mathrm{D}_{3}$ using an established protocol to simulate OTM in vitro [6]. Additionally, we used cells

Table 1 VDR mRNA expression [median (minimum-maximum)] according to the genotypes in each studied SNP in VDR

\begin{tabular}{|c|c|c|c|c|c|c|}
\hline \multirow{3}{*}{$\begin{array}{l}\text { Condition } \\
\text { No pressure }\end{array}$} & \multirow{3}{*}{$\begin{array}{l}\text { SNP and experimental } \\
\text { concentration } \\
\text { Fokl rs2228570 }(G>A)\end{array}$} & \multicolumn{3}{|c|}{ Genotypes median (minimum-maximum) } & \multicolumn{2}{|l|}{$p$ values } \\
\hline & & $G G(n=12)$ & $G A(\mathrm{n}=6)$ & $A A(\mathrm{n}=9)$ & \multirow{2}{*}{$\begin{array}{l}\text { Co-dominant } \\
\text { model }^{\mathrm{a}}\end{array}$} & \multirow{2}{*}{$\begin{array}{l}\text { Recessive } \\
\text { model }^{\mathbf{b}}\end{array}$} \\
\hline & & & & & & \\
\hline & $0 \mathrm{ng} / \mathrm{ml}$ & $0.91(0.01-1.56)$ & $0.98(0.52-1.64)$ & $1.02(0.45-1.58)$ & 0.967 & 0.897 \\
\hline & $40 \mathrm{ng} / \mathrm{ml}$ & $0.85(0.46-1.77)$ & $0.56(0.42-0.96)$ & $0.84(0.28-1.44)$ & 0.173 & 0.439 \\
\hline & Bgll rs739837 (G>T) & $G G(n=9)$ & $G T(n=6)$ & $T T(\mathrm{n}=12)$ & & \\
\hline & $0 \mathrm{ng} / \mathrm{ml}$ & $1.01(0.45-1.58)$ & $1.06(0.74-1.56)$ & $1.03(0.52-1.64)$ & 0.852 & 0.892 \\
\hline & $40 \mathrm{ng} / \mathrm{ml}$ & $0.59(0.28-0.96)$ & $0.95(0.81-1.77)$ & $0.85(0.42-1.44)$ & 0.061 & $0.038^{*}$ \\
\hline & Apal rs7975232 $(A>C)$ & $A A(\mathrm{n}=12)$ & $A C(\mathrm{n}=9)$ & $C C(n=6)$ & & \\
\hline & $0 \mathrm{ng} / \mathrm{ml}$ & $1.03(0.52-1.64)$ & $1.01(0.75-1.56)$ & $1.09(0.45-1.58)$ & 0.943 & 0.922 \\
\hline & $40 \mathrm{ng} / \mathrm{ml}$ & $0.85(0.42-1.44)$ & $0.84(0.53-1.77)$ & $0.54(0.28-0.96)$ & 0.152 & 0.062 \\
\hline \multirow[t]{9}{*}{ Pressure } & Fokl rs2228570 $(A>G)$ & $G G(n=12)$ & $G A(n=6)$ & $A A(\mathrm{n}=9)$ & & \\
\hline & $0 \mathrm{ng} / \mathrm{ml}$ & $0.82(0.49-1.72)$ & $1.20(0.64-3.14)$ & $0.72(0.47-1.58)$ & 0.248 & 0.764 \\
\hline & $40 \mathrm{ng} / \mathrm{ml}$ & $0.59(0.21-0.90)$ & $0.92(0.60-1.39)$ & $0.84(0.18-1.15)$ & 0.122 & 0.235 \\
\hline & Bgll rs739837 (G>T) & $G G(n=9)$ & $G T(n=6)$ & $T T(\mathrm{n}=12)$ & & \\
\hline & $0 \mathrm{ng} / \mathrm{ml}$ & $0.69(0.47-2.14)$ & $0.74(0.49-1.56)$ & $0.86(0.49-1.72)$ & 0.709 & 0.451 \\
\hline & $40 \mathrm{ng} / \mathrm{ml}$ & $0.88(0.18-1.38)$ & $0.68(0.26-0.90)$ & $0.72(0.21-1.15)$ & 0.601 & 0.398 \\
\hline & Apal rs7975232 $(A>C)$ & $A A(\mathrm{n}=12)$ & $A C(\mathrm{n}=9)$ & $C C(n=6)$ & & \\
\hline & $0 \mathrm{ng} / \mathrm{ml}$ & $0.86(0.49-1.72)^{a, b}$ & $0.58(0.47-1.56)^{\mathrm{a}}$ & $1.29(0.54-3.14)^{b}$ & $0.045^{*}$ & $0.048^{*}$ \\
\hline & $40 \mathrm{ng} / \mathrm{ml}$ & $0.73(0.21-1.15)$ & $0.77(0.26-0.98)$ & $0.99(0.19-1.38)$ & 0.683 & 0.581 \\
\hline
\end{tabular}

*Means statistically significant difference $(p<0.05)$. Comparisons were performed among genotypes within the same SNP under the same experimental conditions. Different letters indicate a significant difference

${ }^{a}$ Kruskal-Wallis with Dunn's test was used

${ }^{\mathrm{b}}$ Mann-Whitney test was used 
from different patients, with different genotypes to perform a pilot investigation of the impact of SNPs in VDR gene on mRNA expression of OTM-related target genes.

RANKL, OPG, COX-2 and IL6 are genes differentially expressed during OTM $[8,20,21]$. RANKL is well-known as essential for osteoclast formation [37] and binds to the RANK receptor on osteoclast precursor cells initiating osteoclast formation and differentiation [38], while OPG is the endogenous inhibitor of RANKL. Transgenic mice demonstrated that RANKL produced by PDL cells and bone is the major driving force for osteoclastogenesis in response to OTM [36]. Our study confirmed that RANKL was overexpressed during simulated orthodontic compressive strain and also suggested that the RANKL:OPG ratio increases during pressure. The RANKL:OPG ratio regulates osteoclast differentiation, activation and survival and affects the balance between bone formation and resorption [39], which is pivotal for OTM.

The RANKL:OPG ratio is increased during inflammatory conditions. During OTM a biologic response occurs, which is mediated by a variety of inflammatory cytokines described as an aseptic inflammation [3]. In our study both IL-6 and COX-2 expression increased during simulated orthodontic compressive strain. IL- 6 has been demonstrated to be overexpressed during OTM [40, 41], which can be attributed to the fact that IL- 6 is involved in bone resorption [42], which is required for OTM. Likewise, the expression of COX-2, producing proinflammatory prostaglandins, increases during OTM $[6,40]$ and is also involved in bone resorption [43].

Many studies highlight important control points in vitamin D molecular pathways. Some of the most remarkable genes include $V D R$, which is the receptor that mediates the action of both $25(\mathrm{OH}) \mathrm{D}_{3}$ and $1,25(\mathrm{OH}) 2 \mathrm{D}_{3}$. Other genes, however, are also involved in vitamin $\mathrm{D}$ molecular pathways, such as DHCR7, SEC23A, AMDHD1, CYP2R1 and $C Y P 27 B 1$, which were evaluated here. Interestingly, the expression levels of DHCR7, AMDHD1 and SEC23A changed during simulated orthodontic compressive strain, suggesting that these genes are involved in OTM and the variation in their expression might be involved in clinical outcomes in orthodontic practice. A previous study reported that the conversion of vitamin $\mathrm{D}$ to $1,25(\mathrm{OH}) 2 \mathrm{D}_{3}$ in human gingival and hPDL fibroblasts consisted of two steps, in which the conversion from vitamin $\mathrm{D} 3$ to $25(\mathrm{OH}) \mathrm{D}_{3}$ is under the action of CYP27A1, while the conversion from $25(\mathrm{OH}) \mathrm{D}_{3}$ to $1,25(\mathrm{OH}) 2 \mathrm{D}_{3}$ is under the action of CYP27B1 [28]. Although our studied focused on the evaluation of CYP27B1, future studies should also evaluate the role of CYP27A1 during OTM.

The administration of vitamin $\mathrm{D}$ during orthodontic treatment has been proposed [33] to accelerate the OTM [10-12] and to enhance tooth position stability [15].
These previous studies are contradicting in their results, as the acceleration of OTM requires a high osteoclast activity, while tooth position stability predominantly requires osteoblastic activity [2]. In our study, different concentrations of $25(\mathrm{OH}) \mathrm{D}_{3}$ during simulated orthodontic compressive strain downregulated the RANKL:OPG ratio, which does not support the notion that vitamin D supplementation accelerates OTM. On the contrary, lower levels of the RANKL:OPG ratio should have a decelerating effect on OTM and favor tooth position stability in agreement with Kawakami and Takano-Yamamoto [15].

The role of vitamin D on OTM presented here and in the previous studies [10-12, 15] should be interpreted with caution. Although it is a well-established concept that vitamin $\mathrm{D}$ is important for normal development and maintenance of bone and the skeleton, it is also known that supraphysiological doses of vitamin D stimulate bone resorption. The inhibitory effect of vitamin D on RANKL expression occurred only with physiological doses. On the other hand, supraphysiological doses increased $\mathrm{Ca}^{2+}$ serum and RANKL expression [44, 45]. Studies observing that vitamin D accelerates OTM performed their experiments injecting high doses of vitamin $\mathrm{D}[11,12]$, whereas in our in vitro study we simulated vitamin D deficiency $(10 \mathrm{ng} / \mathrm{ml})$, and vitamin D sufficiency in the lower (40 ng/ $\mathrm{ml})$ and higher $(60 \mathrm{ng} / \mathrm{ml})$ limits. We did not evaluate supraphysiological levels of vitamin D due the fact thatalthough it might improve the OTM-we do not want to encourage a therapy with supraphysiological levels with possible vitamin $\mathrm{D}$ toxicity.

It is not known, if $25(\mathrm{OH}) \mathrm{D}_{3}$ influences the inflammatory response in hPDL cells $[14,30,31]$. In our study, however, COX-2 was not differently expressed among different $25(\mathrm{OH}) \mathrm{D}_{3}$ concentrations and IL-6 did not demonstrate to be differentially expressed among them. In previous studies, the production of pro-inflammatory mediators in the PDL was significantly inhibited by vitamin $\mathrm{D}$ in a periodontal disease model, including IL-6 [14, 31]. Interestingly, Andrukhov et al. [14] found that $25(\mathrm{OH}) \mathrm{D}_{3}$ inhibits IL-6 expression in commercially available hPDL fibroblasts, but not in primary hPDL fibroblasts. Tang et al. [30], Gao et al. [46] and Zhang et al. [47] also observed that vitamin D inhibits IL-8 expression in a periodontal model, but had no effect on IL-6 expression [30]. On the other hand, Nastri et al. [48] observed that IL-6 secretion increased in vitamin-D-treated gingival fibroblasts and hPDL cells exposed to Porphyromonas gingivalis and Streptococcus pyogene, while IL-8 secretion decreased.

The action of $25(\mathrm{OH}) \mathrm{D}_{3}$ is mediated by its receptor VDR and therefore produces its pleiotropic effects via binding with its ligand and operating a cascade of 
signaling pathways inducing the activation of various genes [49]. A concentration-dependent correlation was observed between serum vitamin D levels and VDR concentration in the hPDL tissue [32]. Additionally, Andrukhov et al. [14] performed an experiment silencing the $V D R$ by siRNA, which resulted in the abolishment of the vitamin $\mathrm{D}$ effects in hPDL fibroblasts. The authors concluded that the regulation of expression levels of VDR in hPDL fibroblasts is an important factor influencing functional properties [14]. Although our results do not support that simulated orthodontic compressive strain or $25(\mathrm{OH}) \mathrm{D}_{3}$ supplementation influences $V D R$ mRNA expression, we decided to perform further analyses in order to evaluate, if SNPs in the VDR gene are involved in mRNA expression of this gene in hPDL fibroblasts.

The VDR gene is known to exhibit many SNPs [23], which might influence the expression/functions of VDR in hPDL fibroblasts. It is also associated with complex conditions such as OTM. We selected three common SNPs in the VDR gene, known as FokI, BgII and ApaI, which have been widely explored in the literature and are associated with different phenotypes/conditions including periodontal disease $[25,26]$ and external apical root resorption during orthodontic treatment [27]. Our results from individuals carrying different genotypes suggested that both intronic SNPs evaluated here (BgII and ApaI) could be involved in the regulation of $V D R$ mRNA expression in hPDL fibroblasts. However, it is important to emphasize that this result is restricted to mRNA data and the protein levels were not assessed. Statistical differences in VDR mRNA expression were not observed among the genotypes in FokI-however, this is a missense variation, in which the SNP is responsible for a substitution at exon 2 of the VDR gene. As a result of this substitution, the methionine amino acid is translated to threonine, which could finally affect function and efficacy of the VDR protein [50], instead of the expression level. The influence of FokI on transcriptional activation by VDRs in human gingival fibroblasts and hPDL cells has already been investigated in a previous study. After stimulation with vitamin $\mathrm{D}$, the authors observed that the expression of alkaline phosphatase and osteocalcin were different according to the genotypes in FokI [51]. The presence of the wild allele in FokI was also associated with RANKL measurement in patient's plasma [52]. Therefore, the possibility that SNPs in the VDR gene influence gene and protein expression in hPDL cells contributing to the individual difference in OTM velocity cannot be excluded and requires further investigations.

A previous study observed that elevated vitamin D levels were associated with aggressive periodontitis and that these levels were systemically and locally reduced by initial periodontal therapy [53]. Later, this same research group demonstrated that gingival fibroblasts and hPDL cells have 25 -hydroxylase activity and convert vitamin $\mathrm{D}$ to $1,25(\mathrm{OH}) 2 \mathrm{D}_{3}$ [28]. Therefore, it is possible that OTM has a possible local and/or systemic effect on vitamin D levels and this topic should also be investigated in future clinical studies.

Briefly, our results do not support that physiological concentrations of $25(\mathrm{OH}) \mathrm{D}_{3}$ may enhance the OTM, however it is possibly involved in the reestablishment of bony tissue supporting the teeth after OTM. Also, our results do not support that vitamin D deficiency leads to a slower rate of OTM, as proposed in a recent review [33].

\section{Conclusion}

Simulated orthodontic compressive strain impacted on the expression of OTM- and vitamin-D-related genes. Physiological concentrations of $25(\mathrm{OH}) \mathrm{D}_{3}$ are involved in gene expression variations during simulated orthodontic compressive strain. SNPs in $V D R$ gene may affect mRNA expression of VDR in hPDL fibroblasts.

\begin{abstract}
Abbreviations
PDL: Periodontal ligament; hPDL: Human periodontal ligament; OTM: Orthodontic tooth movement; PCR: Polymerase chain reaction; RANKL: Receptor activator of nuclear factor-KB ligand; OPG: Osteoprotegerin; COX-2: Cyclooxygenase-2; IL-6: Interleukin-6; VDR: Vitamin D receptor; DHCR7: 7-Dehydrocholesterol reductase; SEC23A: Sec23 homolog A; AMDHD1: Amidohydrolase domain containing 1; CYP27B1: Cytochrom P450 familie 27 subfamilie B polypeptid 1; CYP2R1: Cytochrome P450 family 2 subfamily R member 1; RPL22: Ribossomal protein L22; PPIB: Peptidylprolyl isomerase B; CYP27A1: Cytochrome P450 family 27 subfamily A member 1.
\end{abstract}

\section{Supplementary Information}

The online version contains supplementary material available at https://doi. org/10.1186/s12903-021-01740-8.

Additional file 1. Studied target genes and reference genes.

\section{Acknowledgements}

The authors want to thank Mrs. Eva Zaglauer for providing technical assistance as well as the Alexander-von-Humboldt-Foundation (Küchler/Kirschneck, July 2019) and Coordenação de Aperfeiçoamento de Pessoal de Nível SuperiorBrasil (CAPES).

\section{Authors' contributions}

ECK, CK, AS and PP conceived the idea, designed the study and coordinated the experiments. ECK, RS and PP funding support. GS collected the sample. VBT, AS and UN performed the in vitro study. ECK performed the genotyping analysis. ECK and RS performed the statistical analysis. ECK and CK wrote the manuscript. All authors read and approved the final manuscript.

\section{Funding}

Open Access funding enabled and organized by Projekt DEAL. This study was financed in part by the Coordenação de Aperfeiçoamento de Pessoal de Nível Superior-Brasil (CAPES)—Finance Code 001 and Alexander-von-HumboldtFoundation (Küchler/Kirschneck accepted in July 4th, 2019). 


\section{Availability of data and materials}

All data generated or analyzed during this study are available from corresponding authors to any reader directly upon reasonable request.

\section{Declarations}

\section{Ethics approval and consent to participate}

The ethics committee of the University of Regensburg, Germany, approved the collection of the samples and the subsequent experiments (Approval No. 12-170-0150). Informed written consent was obtained with an assent document by all subjects.

\section{Consent for publication}

Not applicable.

\section{Competing interests}

The authors declare that they have no competing interests.

\section{Author details}

'Department of Orthodontics, University of Regensburg, Franz-Josef-Strauss-Allee 11, 93053 Regensburg, Germany. ${ }^{2}$ Private Practice Curitiba, Paraná, Brazil. ${ }^{3}$ Department of Stomatology, Federal University of Paraná, Curitiba, Paraná, Brazil. ${ }^{4}$ Department of Maxillofacial Surgery, University of Regensburg, Regensburg, Germany.

\section{Received: 23 June 2021 Accepted: 23 July 2021}

Published online: 06 August 2021

\section{References}

1. Jonsson D, Nebel D, Bratthall G, et al. The human periodontal ligament cell: a fibroblast-like cell acting as an immune cell. J Periodontal Res. 2011;46:153-7.

2. Li Y, Jacox LA, Little SH, et al. Orthodontic tooth movement: the biology and clinical implications. Kaohsiung J Med Sci. 2018;34:207-14.

3. Meikle MC. The tissue, cellular, and molecular regulation of orthodontic tooth movement: 100 years after Carl Sandstedt. Eur J Orthod. 2006;28:221-40.

4. Kapoor P, Kharbanda OP, Monga N, et al. Effect of orthodontic forces on cytokine and receptor levels in gingival crevicular fluid: a systematic review. Prog Orthod. 2014;15:65.

5. Kirschneck C, Batschkus S, Proff P, et al. Valid gene expression normalization by RT-qPCR in studies on hPDL fibroblasts with focus on orthodontic tooth movement and periodontitis. Sci Rep. 2017;7:14751.

6. Schröder A, Bauer K, Spanier G, et al. Expression kinetics of human periodontal ligament fibroblasts in the early phases of orthodontic tooth movement. J Orofac Orthop. 2018;79:337-51.

7. Fleissig O, Reichenberg E, Tal M, et al. Morphologic and gene expression analysis of periodontal ligament fibroblasts subjected to pressure. Am J Orthod Dentofac Orthop. 2018;154:664-76.

8. Küchler EC, Schröder A, Corso P, et al. Genetic polymorphisms influence gene expression of human periodontal ligament fibroblasts in the early phases of orthodontic tooth movement. Odontology. 2019;108:493-502.

9. Alhashimi N, Frithiof L, Brudvik P, et al. Orthodontic tooth movement and de novo synthesis of proinflammatory cytokines. Am J Orth Dent Orth. 2001:119:307-12.

10. Boyce RW, Weisbrode SE. Histogenesis of hyperosteoidosis in $1,25(\mathrm{OH}) 2 \mathrm{D}_{3}$-treated rats fed high levels of dietary calcium. Bone. 1985;6:105-12.

11. Collins MK, Sinclair PM. The local use of vitamin D to increase the rate of orthodontic tooth movement. Am J Orthod Dentofac Orthop. 1988;94:278-84.

12. Kale $S$, Kocadereli I, Atilla $\mathrm{P}$, et al. Comparison of the effects of 1,25 dihydroxycholecalciferol and prostaglandin E2 on orthodontic tooth movement. Am J Orthod Dentofac Orthop. 2004;125:607-14.

13. Tang $X$, Meng H. Osteogenic induction and 1,25-dihydroxyvitamin $D_{3}$ oppositely regulate the proliferation and expression of RANKL and the vitamin D receptor of human periodontal ligament cells. Arch Oral Biol. 2009;54:625-33.
14. Andrukhov $\mathrm{O}$, Andrukhova $\mathrm{O}$, Hulan $\mathrm{U}$, et al. Both 25 -hydroxyvitamin- $\mathrm{D}_{3}$ and 1,25-dihydroxyvitamin- $\mathrm{D}_{3}$ reduces inflammatory response in human periodontal ligament cells. PLOS ONE. 2014;28:9e90301.

15. Kawakami M, Takano-Yamamoto T. Local injection of 1,25-dihydroxyvitamin $D_{3}$ enhanced bone formation for tooth stabilization after experimental tooth movement in rats. J Bone Miner Metab. 2004;22:541-6.

16. Randev S, Kumar P, Guglani V. Vitamin D supplementation in childhood_a review of guidelines. Indian J Pediatr. 2018;85:194-201.

17. Bikle DD. Vitamin D metabolism, mechanism of action, and clinical applications. Chem Biol. 2014;21:319-29.

18. Haussler MR, Whitfield GK, Haussler CA, et al. The nuclear vitamin D receptor: biological and molecular regulatory properties revealed. J Bone Miner Res. 1998:13:325-49.

19. Jiang $X$, Kiel DP, Kraft P. The genetics of vitamin D. Bone 2019;126:59-77.

20. Ren Y, Maltha JC, Kuijpers-Jagtman AM. Optimum force magnitude for orthodontic tooth movement: a systematic literature review. Angle Orthod. 2003;73:86-92.

21. Li B, Zhang $Y H$, Wang $L X$, et al. Expression of $O P G, R A N K L$, and RUNX2 in rabbit periodontium under orthodontic force. Genet Mol Res. 2015;14:19382-8

22. Miyamoto $\mathrm{K}$, Kesterson RA, Yamamoto $\mathrm{H}$. Structural organization of the human Vitamin D receptor chromosomal gene and its promoter. Mol Endocrinol. 1997;11:1165-79.

23. Uitterlinden AG, Fang Y, Van Meurs JB, et al. Genetics and biology of vitamin D receptor polymorphisms. Gene. 2004;338:143-6.

24. Martelli FS, Martelli M, Rosati C, et al. Vitamin D: relevance in dental practice. Clin Cases Miner Bone Metab. 2014;11:15-9.

25. Brito Júnior RB, Scarel-Caminaga RM, Trevilatto PC, et al. Polymorphisms in the vitamin $D$ receptor gene are associated with periodontal disease. J Periodontol. 2004;75:1090-5.

26. Tanaka K, Miyake Y, Hanioka T, et al. VDR gene polymorphisms, interaction with smoking and risk of periodontal disease in Japanese women: the Kyushu Okinawa maternal and child health study. Scand J Immunol. 2013;78:371-7.

27. Fontana ML, de Souza CM, Bernardino JF, et al. Association analysis of clinical aspects and vitamin D receptor gene polymorphism with external apical root resorption in orthodontic patients. Am J Orthod Dentofac Orthop. 2012;142:339-47

28. Liu K, Meng H, Hou J. Activity of 25-hydroxylase in human gingival fibroblasts and periodontal ligament cells. PLoS ONE. 2012;7:e52053.

29. Liu K, Meng H, Hou J. Characterization of the autocrine/paracrine function of vitamin D in human gingival fibroblasts and periodontal ligament cells. PLoS ONE. 2012;7:e39878.

30. Tang $X$, Pan $Y$, Zhao Y. Vitamin D inhibits the expression of interleukin8 in human periodontal ligament cells stimulated with Porphyromonas gingivalis. Arch Oral Biol. 2013;58:397-407.

31. Nebel D, Svensson D, Arosenius K, et al. 1a,25-dihydroxyvitamin D3 promotes osteogenic activity and downregulates proinflammatory cytokine expression in human periodontal ligament cells. J Periodontal Res. 2015:50:666-73.

32. Patil VS, Mali RS, Moghe AS. Evaluation and comparison of Vitamin D receptors in periodontal ligament tissue of Vitamin D-deficient chronic periodontitis patients before and after supplementation of Vitamin $D_{3}$. J Indian Soc Periodontol. 2019:23:100-5.

33. Almoammar K. Vitamin D and orthodontics: an insight review. Clin Cosmet Invest Dent. 2018;10:165-70.

34. Holick MF, Binkley NC, Bischoff-Ferrari HA, et al. Evaluation, treatment, and prevention of vitamin D deficiency: an Endocrine Society clinical practice guideline. J Clin Endocrinol. 2011;96:1911-30.

35. Bustin SA, Benes V, Garson JA, Hellemans J, Huggett J, Kubista M, Mueller R, Nolan T, Pfaffl MW, Shipley GL, Vandesompele J, Wittwer CT. The MIQE guidelines: minimum information for publication of quantitative real-time PCR experiments. Clin Chem. 2009;55:611-22.

36. Yang CY, Jeon HH, Alshabab A, Lee YJ, Chung CH, Graves DT. RANKL deletion in periodontal ligament and bone lining cells blocks orthodontic tooth movement. Int J Oral Sci. 2018;10:3.

37. Yasuda H, Shima N, Nakagawa N, et al. Osteoclast differentiation factor is a ligand for osteoprotegerin/osteoclastogenesis-inhibitory factor and is identical to TRANCE/RANKL. Proc Natl Acad Sci USA. 1998:95:3597-602. 
38. Boyle WJ, Simonet WS, Lacey DL. Osteoclast differentiation and activation. Nature. 2003;423:337-42.

39. Simonet WS, Lacey DL, Dunstan CR, et al. Osteoprotegerin: a novel secreted protein involved in the regulation of bone density. Cell. 1997:89:309-19.

40. Kirschneck C, Proff P, Maurer M, et al. Orthodontic forces add to nicotineinduced loss of periodontal bone: an in vivo and in vitro study. J Orofac Orthop. 2015;76:195-212.

41. Madureira DF, Taddei SA, Abreu MH, et al. Kinetics of interleukin-6 and chemokine ligands 2 and 3 expression of periodontal tissues during orthodontic tooth movement. Am J Orthod Dentofac Orthop. 2012;142:494-500.

42. Fonseca JE, Santos MJ, Canhao H, et al. Interleukin-6 as a key player in systemic inflammation and joint destruction. Autoimmun Rev. 2009;8:538-42.

43. Okada Y, Pilbeam C, Raisz L, et al. Role of cyclooxygenase-2 in bone resorption. J UOEH. 2003;25:185-95.

44. Suda T, Ueno Y, Fujii K, et al. Vitamin D and bone. J Cell Biochem. 2003;88:259-66.

45. Gil Á, Plaza-Diaz J, Mesa MD. Vitamin D: classic and novel actions. Ann Nutr Metab. 2018;72:87-95.

46. Gao Z, Liu K, Meng H. Preliminary investigation of the vitamin D pathway in periodontal connective tissue cells. J Periodontol. 2018;89:294-302.

47. Zhang C, Liu K, Hou J. Extending the vitamin D pathway to vitamin D 3 and CYP27A1 in periodontal ligament cells. J Periodontol. 2020;26:44-53.

48. Nastri L, Guida L, Annunziata M, Ruggiero N, Rizzo A. Vitamin D modulatory effect on cytokines expression by human gingival fibroblasts and periodontal ligament cells. Minerva Stomatol. 2018;67:102-10.
49. Bikle DD. The vitamin D receptor: a tumor suppressor in skin. Discov Med. 2011;11:7-17.

50. Gennari L, Becherini L, Mansani R, et al. Fokl polymorphism at translation initiation site of the vitamin D receptor gene predicts bone mineral density and vertebral fractures in postmenopausal Italian women. J Bone Miner Res. 1999;14:1379-2138.

51. Liu K, Han B, Meng H, Hou J. Influence of rs 2228570 on transcriptional activation by the vitamin $D$ receptor in human gingival fibroblasts and periodontal ligament cells. J Periodontol. 2017;88:915-25.

52. Sansoni V, Perego S, Colombini A, Banfi G, Brayda-Bruno M, Lombardi G. Interplay between low plasma RANKL and VDR-Fokl polymorphism in lumbar disc herniation independently from age, body mass, and environmental factors: a case-control study in the Italian population. Eur Spine J. 2020;29:924.

53. Liu K, Meng H, Lu R, Xu L, Zhang L, et al. Initial periodontal therapy reduced systemic and local 25-hydroxy vitamin D(3) and interleukin1 beta in patients with aggressive periodontitis. J Periodontol. 2010;81:260-6.

\section{Publisher's Note}

Springer Nature remains neutral with regard to jurisdictional claims in published maps and institutional affiliations.
Ready to submit your research? Choose BMC and benefit from:

- fast, convenient online submission

- thorough peer review by experienced researchers in your field

- rapid publication on acceptance

- support for research data, including large and complex data types

- gold Open Access which fosters wider collaboration and increased citations

- maximum visibility for your research: over $100 \mathrm{M}$ website views per year

At BMC, research is always in progress.

Learn more biomedcentral.com/submissions 